Vol.24, No.2, 129-139, November 2021

DOI : https://doi.org/10.18196/st.v24i2.12938

\title{
Rancang Bangun Alat Ukur Medan Magnet Berbasis Arduino Uno Menggunakan Sensor Efek Hall
}

\author{
(Arduino Uno-Based Magnetic Field Measurement Tool Using Hall Effect Sensor)
}

\author{
LENI YANTI WARUWU, AIDHIA RAHMI, MEGASYANI ANAPERTA
}

\begin{abstract}
ABSTRAK
Alat ukur medan magnet digital yang dijual di pasaran saat ini memiliki harga yang relatif mahal, maka dibuatlah alat ukur medan magnet yang sederhana dengan fungsi yang sama dengan alat ukur medan magnet yang dijual di pasaran. Alat ukur ini terdiri dari lima bagian utama yaitu adaptor, selenoida, sensor efek hall, arduino uno dan OLED. Alat ukur medan magnet yang dibuat akan digunakan untuk mengetahui hasil pengukuran medan magnet terhadap variasi jarak selenoida, medan magnet terhadap jumlah lilitan kawat dan arus listrik pada selenoida, dan perbandingan pengukuran medan magnet terhadap jumlah lilitan kawat dan arus listrik pada selenoida menggunakan alat ukur acuan. Hasil pengukuran medan magnet terhadap jarak menunjukkan bahwa semakin dekat jarak sensor dengan lilitan maka semakin besar medan magnet yang terbaca oleh sensor. Hasil pengukuran medan magnet terhadap jumlah lilitan dan arus listrik menghasilkan medan magnet yang besar apabila jumlah lilitan magnet semakin banyak dan arus yang dibesikan semakin besar. \% error untuk medan magnet terhadap jarak, jumlah lilitan dan arus listrik sebesar $14.60 \%, 1.42 \%$, dan $0.44 \%$.
\end{abstract}

Kata kunci: Medan Magnet, Sensor Efek Hall, Arduino Uno.

\section{ABSTRACT}

Digital magnetic field meters on the market today are relatively expensive, making simple magnetic field meters with the same functions as commercially available magnetic field meters. This meter consists of 5 main parts: adapter, solenoid, hall effect sensor, Arduino Uno and OLED. The magnetic field meter is used to determine the magnetic field measurement result for the change in the solenoid distance, the magnetic field measurement result according to the number of turns of the conductor and current of the solenoid. The magnetic field is the number of turns of wire and current in the solenoid using a reference meter. Measurements of magnetic field versus distance indicate that the closer the sensor is to the coil, the greater the magnetic field the sensor reads. The magnetic field measurement results for the number of revolutions and the current produce a large magnetic field when the number of revolutions increases and the current supplied is more. The \% errors for magnetic field over distance, number of revolutions and current are 14.60\%, 1.42\%, and $0.44 \%$.

Keywords: Magnetic field, Hall Effect Sensor, Arduino Uno.

\section{PENDAHULUAN}

Medan magnet adalah daerah di sekitar magnet yang masih dipengaruhi oleh magnet. Medan magnet terjadi karena adanya kutub-kutub magnet yang memiliki gaya tarik-menarik dan tolak-menolak yang besar (Novitasari, dkk. 2019).
Pada tahun 1820 seorang ilmuan Denmark Hans Christian Oersted (1777-1857) menemukan suatu gejala yang menarik. Dalam percobaannya, ia menggunakan sebuah kompas jarum untuk menunjukkan bahwa ketika arus listrik mengalir pada seutas kawat, jarum kompas yang diletakkan pada daerah medan magnetik yang dihasilkan oleh kawat berarus menyebabkan jarum kompas 
menyimpang dari arah utara ke selatan. Kemudian disimpulkan bahwa di sekitar kawat berarus timbul medan magnet. Medan magnet oleh kawat berarus inilah yang dinamakan dengan induksi magnet (Ardiansyah, 2019). Salah satu contoh dari induksi magnet yaitu selenoida.

Persamaan yang digunakan untuk menghitung induksi magnet pada ujung selenoida yaitu:

$B=\frac{\mu_{0} N I}{2 l}$

dengan $B=$ Besar Induksi Magnet dalam satuan Tesla (T), $N=$ Banyak Lilitan Kawat Selenoida, $I=$ Kuat Arus listrik dalam satuan Ampere (A), $l=$ Panjang Selenoida dalam satuan meter $(\mathrm{m}), \mu_{0}=$ Permeabilitas Vakum $\left(4 \pi \times 10^{-7} \mathrm{~Wb} / \mathrm{Am}\right)$

Umumnya alat ukur medan magnet terbagi menjadi alat ukur analog dan alat ukur digital. Namun alat ukur analog memiliki resolusi yang kurang baik karena menggunakan jarum sebagai penunjuk, sehingga sering terjadi kesalahan pembacaan saat melakukan pengukuran, sedangkan alat ukur digital memiliki harga yang relatif mahal (Erlangga, 2017)

Alat ukur medan magnet sebelumnya telah dibuat oleh Pambuka \& Rahardjo (2018) dengan mengukur medan magnet yang terdapat pada toroida. Pambuka melakukan pengukuran dengan memvariasikan jumlah lilitan kawat dan arus listrik pada toroida.

Berdasarkan permasalahan dan hasil penelitian sebelumnya, maka dalam penelitian ini telah berhasil merancang alat ukur medan magnet menggunakan sensor efek hall dengan melakukan pengukuran medan magnet pada selenoida dengan memvariasikan jarak ukur, jumlah lilitan dan arus listrik.

Alat yang digunakan untuk mendeteksi medan magnet yang digunakan adalah sensor efek hall. Sensor Efek hall merupakan sensor yang digunakan untuk mendeteksi medan magnet. Sensor ini terdiri dari sebuah lapisan silikon yang berfungsi untuk mengalirkan arus listrik (Premono, dkk. 2015)
Sensor efek Hall memiliki tiga pin yaitu:

1. Pin 1 adalah supply yang berfungsi sebagai sumber tegangan yang diberikan ke dalam sensor efek hall agar sensor dapat bekerja.

2. Pin 2 adalah ground.

3. Pin 3 adalah output yang berfungsi sebagai tegangan yang diperoleh dari medan magnet yang terukur.

Pemprosesan sinyal yang digunakan adalah arduino. Arduino adalah papan elektonik yang menggunakan mikrokontroler untuk membuat projek berbasis pemprograman. Contoh arduino yang paling banyak digunakan, yaitu arduino uno. Arduino uno dibekali dengan mikrokontroler dan dilengkapi dengan berbagai hal yang dibutuhkan untuk mendukung mikrokontroler untuk bekerja. ATMega328P yang sudah terbentuk modul (Junaidi \& Prabowo, 2018).

Arduino Uno memiliki 14 digital pin input/output (atau biasa ditulis I/O, dimana 6 pin diantaranya dapat digunakan sebagai output PWM), 6 pin input analog, menggunakan cristal $16 \mathrm{MHz}$, koneksi USB, jack listrik, header ICSP dan tombol reset. Hal tersebut adalah semua yang diperlukan untuk mendukung sebuah rangkaian mikrokontroler. Cukup dengan menghubungkannya ke komputer dengan kabel USB atau diberi power dengan adaptor AC-DC atau baterai. Kerusakan paling buruk yang terjadi hanyalah kerusakan pada chip ATMega328, yang bisa diganti sendiri dengan mudah dan dengan harga yang relatif murah (Suwarti, 2018).

\section{Metode Penelitian}

Jenis penelitian yang digunakan bersifat eksperimen. Menurut Prasetyo, dkk (2020) eksperimen adalah salah satu metode dalam ilmu pengetahuan untuk menemukan jawaban atas pertanyaan sementara atau hipotesis secara ilmiah.

\section{Tahap Perancangan Sistem}

Secara umum proses perancangan sistem alat ukur medan magnet seperti Gambar 1. 


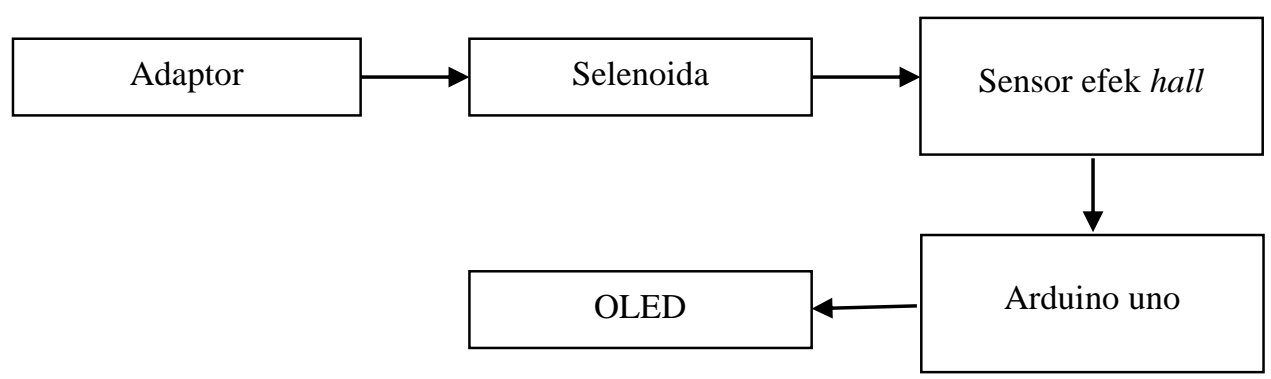

GAMBAR 1. Diagram Perancangan Sistem

Adaptor dihubungkan pada dua ujung kawat selenoida. Setelah adaptor dihubungkan pada selenoida, maka arus listrik akan mengalir pada selenoida. Selenoida dibuat dengan cara kawat dililit secara melingkar pada inti besi, lilitan kawat yang digunakan pada penelitian ini yaitu 1000 lilitan, 1200 lilitan dan 1400 lilitan, dengan panjang selenoida yang dialiri arus listrik kemudian dideteksi oleh sensor efek hall.

Sensor efek hall merupakan sensor analog yang menghasilkan keluaran berupa tegangan, selanjutnya hasil tersebut akan diproses oleh arduino uno.

Sebelum sinyal diterima oleh arduino bentuk sinyal tegangan masih berupa analog dan harus dikonversikan ke bentuk digital, sehingga OLED mampu membaca data yang diterima. OLED digunakan untuk menampilkan data yang dikirim oleh arduino uno, untuk menampilkan data ini maka dibutuhkan sebuah software. Software yang digunakan yaitu software Arduino IDE.

\section{Pembuatan Prototipe Alat}

Pembuatan prototipe alat ukur medan magnet terdiri dari dua tahapan, yaitu pembuatan perangkat keras dan pembuatan perangkat lunak. Bentuk ini akan diuraikan masingmasing tahapan sebagai berikut.

\section{a. Pembuatan Perangkat Keras}

Skema rangkaian dari alat dan bahan untuk membuat prototipe alat ukur medan magnet dibuat menggunakan program Fritzing. Gambar 2 menunjukkan skema rangkaian secara keseluruhan.

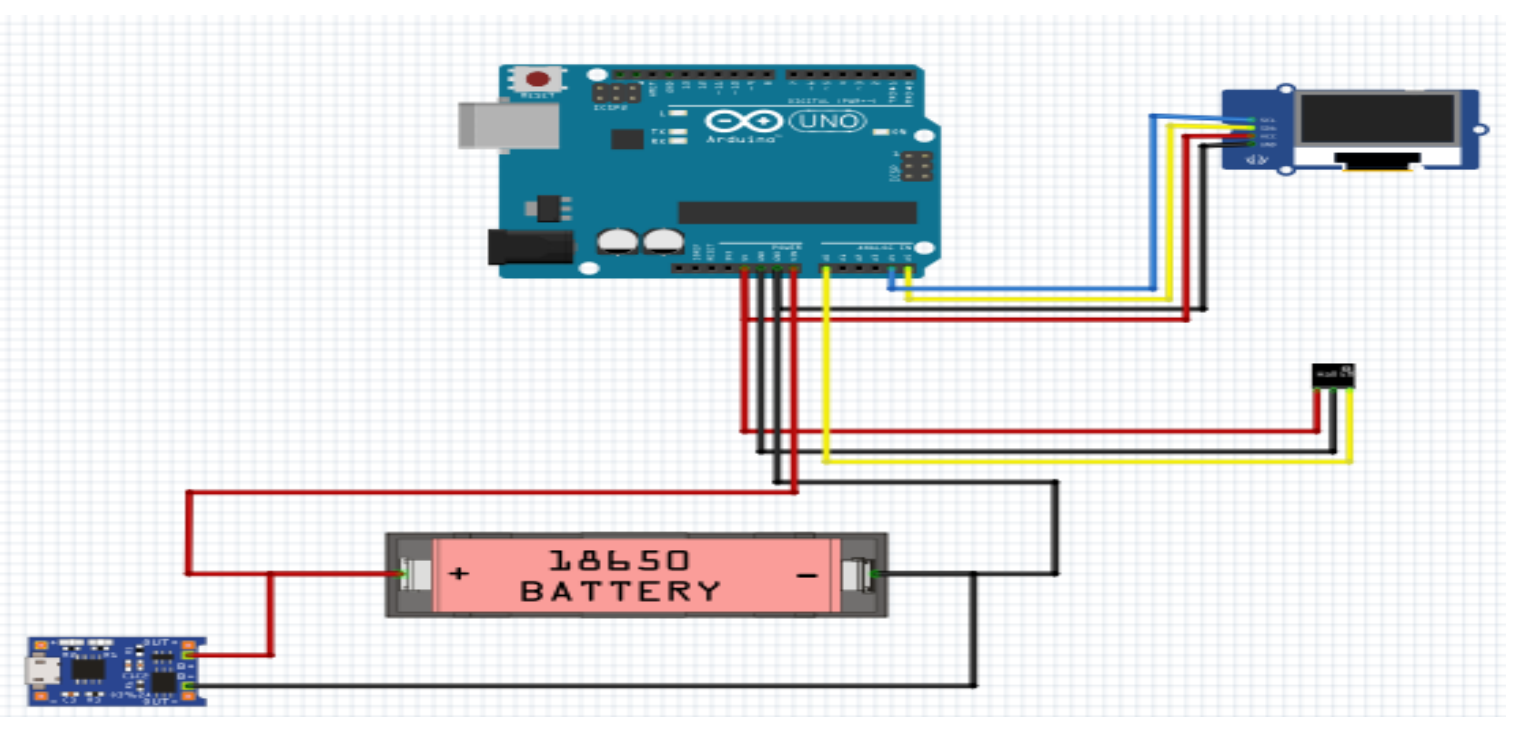

GAMBAR 2. Skema Keseluruhan Rangkaian 


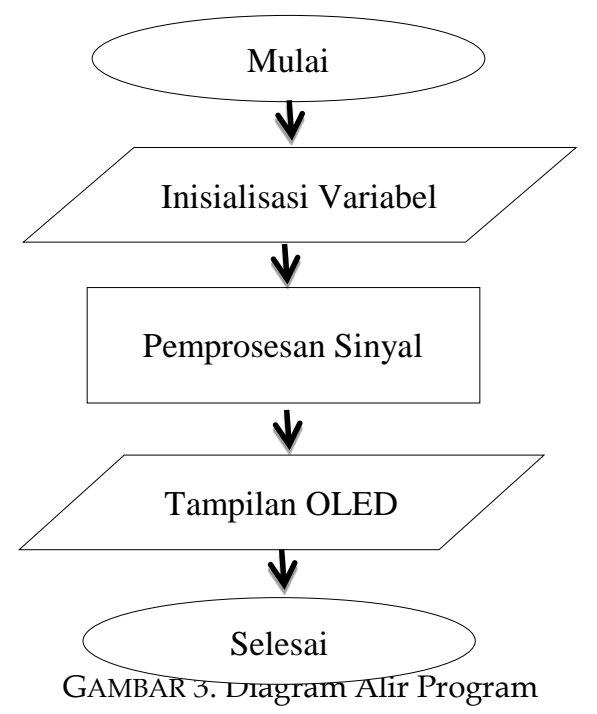

\section{b. Pembuatan Perangkat Lunak}

Proses pembuatan diagram alir program ditunjukkan pada Gambar 3. Penjelasan diagram alir program sebagai berikut.

1) Mulai: memulai jalannya program.

2) Inisialisasi variabel: menganalisa serta mengidentifikasi variabel input yang terdeteksi pada sensor efek hall.

3) Pemrosesan sinyal: sinyal yang diinput oleh sensor efek hall dalam bentuk analog kemudian diterima oleh arduino uno dan sinyal diubah menjadi sinyal digital.

4) Tampilkan pada OLED: menampilkan data hasil nilai pengukuran dalam papan OLED.

5) Selesai: mengakhiri jalannya program.

Penginputan diagram alir tersebut ke dalam sketch dari program Arduino IDE.

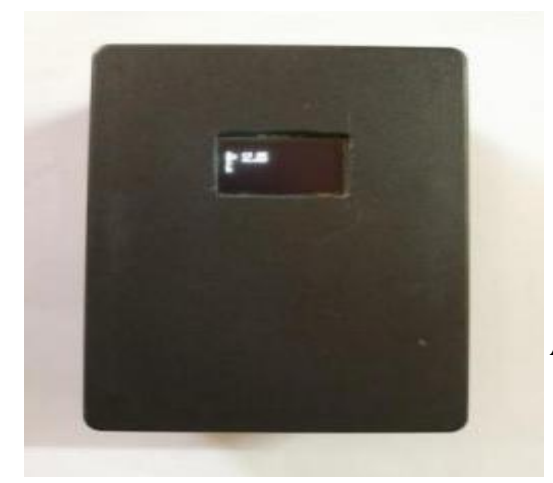

(a)

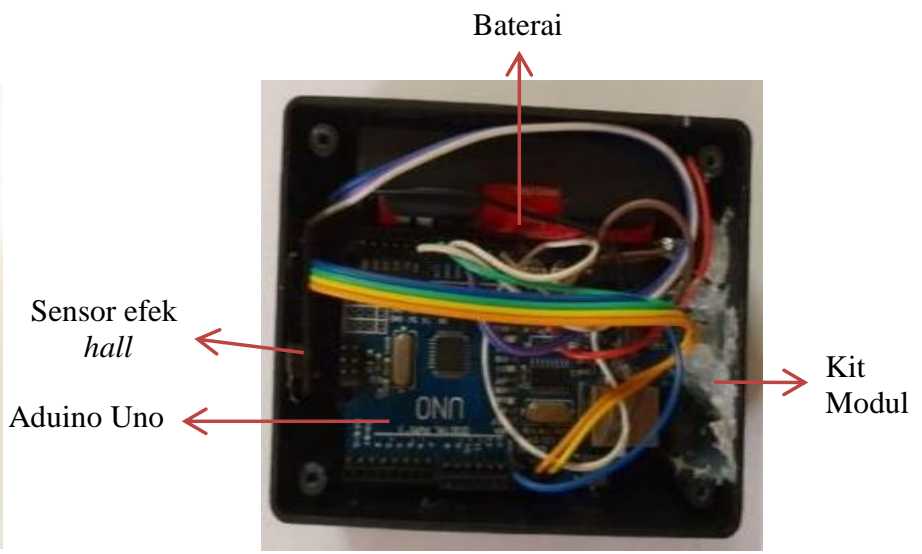

(b)

GAMBAR 4. Hasil Rangkaian Alat Ukur Medan Magnet (a) tampak depan, (b) tampak dalam 


\section{Pengukuran Medan Magnet terhadap Variasi Jarak Selenoida}

Pengujian alat ukur medan magnet berdasarkan variasi jarak selenoida dengan sensor efek hall. Menggunakan 1000 lilitan, 1200 lilitan dan 1400 lilitan. Jarak ukur selenoida dengan sensor dimulai dari $0.2 \mathrm{~cm}$, karena merupakan jarak terdekat yang mampu dideteksi oleh sensor.

\section{a. Selenoida dengan 1000 Lilitan}

Selenoida yang digunakan dengan panjang 5 $\mathrm{cm}$ dan lilitan sebanyak 1000 lilitan. Setelah dilakukan pengukuran, maka didapatkan hasil pembacaan medan magnet untuk 1000 lilitan selenoida seperti Tabel 1.

Dari hasil pengukuran pada Tabel 1, medan magnet yang dihasilkan selenoida dapat terbaca oleh sensor efek hall pada jarak terdekat $0,2 \mathrm{~cm}$ sebesar $62.4 \mathrm{mG}$, sedangkan jarak terjauh yang mampu dibaca oleh sensor efek hall pada jarak $5 \mathrm{~cm}$ yaitu 14,3 mG. Medan magnet yang terbaca oleh alat ukur acuan dengan jarak 0.2 sebesar $56.8 \mathrm{mG}$, pada jarak $5 \mathrm{~cm}$ sebesar $17.9 \mathrm{mG}$.

\section{b. Selenoida dengan 1200 Lilitan}

Setelah dilakukan pengukuran, maka didapatkan hasil pembacaan medan magnet untuk 1200 lilitan selenoida seperti Tabel 2.

Dari hasil pengukuran pada Tabel 2 medan magnet yang dihasilkan selenoida dapat terbaca oleh sensor efek hall pada jarak terdekat $0,2 \mathrm{~cm}$ sebesar $80.2 \mathrm{mG}$, sedangkan jarak terjauh yang mampu dibaca oleh sensor efek hall pada jarak $5 \mathrm{~cm}$ yaitu $15.5 \mathrm{mG}$. Medan magnet yang terbaca oleh alat ukur acuan pada jarak terdekat $0.2 \mathrm{~cm}$ dan jarak terjauh $5 \mathrm{~cm}$ adalah $71.3 \mathrm{mG}$ dan $18.0 \mathrm{mG}$.

c. Selenoida dengan 1400 Lilitan

Setelah dilakukan pengukuran, maka didapatkan hasil pembacaan medan magnet untuk 1400 lilitan selenoida seperti Tabel 3.

Dari hasil pengukuran pada Tabel 3 medan magnet yang dihasilkan selenoida dapat terbaca oleh sensor efek hall pada jarak terdekat $0,2 \mathrm{~cm}$ sebesar $90.5 \mathrm{mG}$, sedangkan jarak terjauh yang mampu dibaca oleh sensor efek hall pada jarak $5 \mathrm{~cm}$ yaitu $18.4 \mathrm{mG}$. Medan magnet yang terbaca oleh alat ukur acuan pada jarak terdekat $0.2 \mathrm{~cm}$ dan jarak terjauh $5 \mathrm{~cm}$ adalah $85.3 \mathrm{mG}$ dan $26.4 \mathrm{mG}$.

TABEL 1. Hasil Pengukuran Medan Magnet Terhadap Variasi Jarak Selenoida dengan N = 1000 Lilitan

\begin{tabular}{cccc}
\hline No. & Jarak (cm) & $\begin{array}{c}\text { Medan magnet (mG) } \\
\text { menggunakan alat ukur } \\
\text { buatan }\end{array}$ & $\begin{array}{c}\text { Medan Magnet (mG) } \\
\text { menggunakan alat ukur } \\
\text { acuan }\end{array}$ \\
\hline 1. & 0.2 & 62.4 & 56.8 \\
2. & 1 & 40.2 & 44.5 \\
3. & 2 & 30.5 & 39.7 \\
4. & 3 & 25.7 & 30.2 \\
5. & 4 & 18.5 & 22.9 \\
6. & 5 & 14.3 & 17.9 \\
\hline
\end{tabular}

TABEL 2. Hasil Pengukuran Medan Magnet Terhadap Variasi Jarak Selenoida dengan N = 1200 Lilitan

\begin{tabular}{cccc}
\hline \multirow{2}{*}{ No. } & \multirow{2}{*}{ Jarak (cm) } & \multicolumn{2}{c}{ Medan Magnet (mG) } \\
\cline { 2 - 4 } & & Alat Ukur Buatan & Alat Ukur Acuan \\
\hline 1. & 0.2 & 80.2 & 71.3 \\
2. & 1 & 46.5 & 58.8 \\
3. & 2 & 37.3 & 44.8 \\
4. & 3 & 28.5 & 33.3 \\
5. & 4 & 18.7 & 24.2 \\
6. & 5 & 15.5 & 18.0 \\
\hline
\end{tabular}




\section{Pengukuran Medan Magnet terhadap Jumlah Lilitan Kawat dan Arus Listrik pada Selenoida}

Hasil pengukuran medan magnet terhadap jumlah lilitan kawat dan arus listrik pada selenoida dapat dilihat pada Tabel 4.

Pengukuran medan magnet terhadap jumlah lilitan kawat menggunakan alat ukur buatan menghasilkan medan magnet sebesar $62.4 \mathrm{mG}$, $80.2 \mathrm{mG}, 90.5 \mathrm{mG}$ dengan variasi jumlah lilitan 1000 lilitan, 1200 lilitan, 1400 lilitan, arus listrik yang diberikan 0.8 A. Menggunakan alat ukur acuan diperoleh medan magnet sebesar $56.8 \mathrm{mG}, 71.3 \mathrm{mG}$, $85.3 \mathrm{mG}$ dengan variasi jumlah lilitan 1000 lilitan, 1200 lilitan, 1400 lilitan arus listrik yang diberikan 0.8 A. Sedangkan pengukuran medan magnet terhadap arus listrik menghasilkan medan magnet sebesar $62.4 \mathrm{mG}$, $75.4 \mathrm{mG}, 80.3 \mathrm{mG}$ dan $100.7 \mathrm{mG}$ pada variasi arus listrik $0.8 \mathrm{~A}, 1.55 \mathrm{~A}, 2.31 \mathrm{~A}$ dan $3.12 \mathrm{~A}$ dengan jumlah lilitan yang digunakan adalah 1000 lilitan. Alat ukur yang dibuat memiliki lima komponen utama yaitu adaptor, selenoida, sensor efek hall, arduino uno dan OLED. Komponen tersebut dirangkai sesuai dengan tahapan pembuatan perangkat keras. Kemudian alat ini dapat mengukur medan magnet pada selenoida, dari hasil pengukuran tersebut dapat dilihat hubungan antara medan magnet terhadap jarak, jumlah lilitan kawat dan arus listrik.

TAbel 3. Hasil Pengukuran Medan Magnet Terhadap Variasi Jarak Selenoida dengan N = 1400 Lilitan

\begin{tabular}{cccc}
\hline \multirow{2}{*}{ No. } & \multirow{2}{*}{ Jarak $(\mathbf{c m})$} & \multicolumn{2}{c}{ Medan Magnet $(\mathbf{m G})$} \\
\cline { 3 - 4 } & & Alat Ukur Buatan & Alat Ukur Acuan \\
\hline 1. & 0.2 & 90.5 & 85.3 \\
2. & 1 & 70.5 & 76.7 \\
3. & 2 & 55.2 & 61.0 \\
4. & 3 & 40.8 & 46.4 \\
5. & 4 & 29.5 & 34.6 \\
6. & 5 & 18.4 & 26.4 \\
\hline
\end{tabular}

TABEL 4. Hasil Pengukuran Medan Magnet Terhadap Jumlah Lilitan Kawat dan Arus Listrik pada Selenoida

\begin{tabular}{cccc}
\hline \multirow{2}{*}{ Arus Listrik } & Jumlah Lilitan & \multicolumn{2}{c}{ Medan Magnet (mG) } \\
\cline { 3 - 4 } & & Alat Ukur Buatan & Alat Ukur Acuan \\
\hline \multirow{2}{*}{$0.8 \mathrm{~A}$} & 1000 & 62.4 & 56.8 \\
& 1200 & 80.2 & 71.3 \\
& 1400 & 90.5 & 85.3 \\
$1.55 \mathrm{~A}$ & 1000 & 75.4 & 68.1 \\
& 1200 & 100.2 & 93.8 \\
$2.31 \mathrm{~A}$ & 1400 & 116.7 & 108.5 \\
& 1000 & 80.3 & 75.2 \\
& 1200 & 121.1 & 110.6 \\
$3.12 \mathrm{~A}$ & 1400 & 125.4 & 120.3 \\
& 1000 & 100.7 & 94.2 \\
& 1200 & 127.8 & 122.0 \\
& 1400 & 134.5 & 127.6 \\
\hline
\end{tabular}




\section{Hubungan Medan Magnet terhadap Variasi Jarak Selenoida}

Hasil dari pengukuran medan magnet terhadap variasi jarak ukur sensor efek hall dengan selenoida, maka didapatkan grafik hubungan medan magnet terhadap variasi jarak seperti pada Gambar 5.

Hasil pembacaan sensor efek hall terhadap variasi jarak selenoida didapatkan bahwa semakin dekat jarak sensor dengan selenoida, maka semakin besar medan magnet yang terukur oleh alat ukur digital. Hal ini menunjukkan bahwa respon sensor menjadi kurang responsif ketika jarak pengukuran cukup jauh. Saat posisi sensor efek hall menjauhi selenoida maka besar medan magnet akan mengalami penurunan. Penurunan ini diakibatkan karena jumlah garis gaya magnet yang diterima oleh elemen hall sensor semakin lama semakin berkurang, dikarenakan posisi sensor yang menjauhi selenoida.

Dalam aplikasinya, sensor efek hall mampu melakukan pengukuran pada rentang yang cukup kecil antara sensor dengan selenoida yaitu dalam orde milimeter. Artinya sensor efek hall sangat sensitif pada perubahan jarak yang sangat dekat.

Menurut Salomo, dkk (2016) bahwa nilai medan magnet akan semakin mengecil ketika jarak pengukuran semakin jauh, hal ini disebabkan oleh semakin kecilnya kontribusi fluks magnet dari kumparan yang menghasilkan medan magnet tersebut.

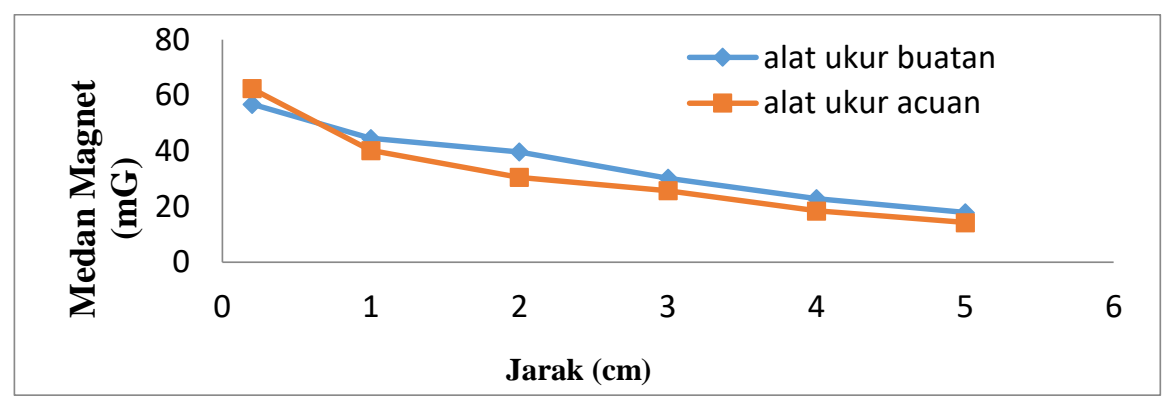

(a)

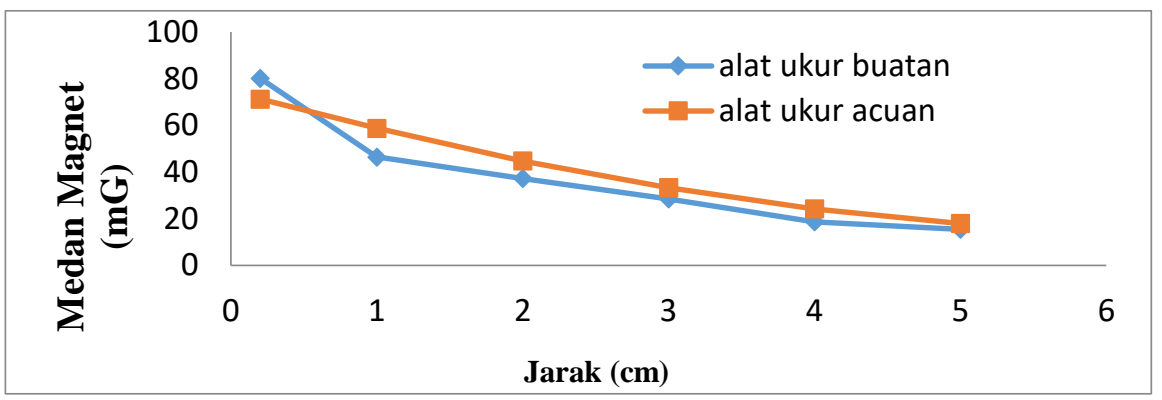

(b)

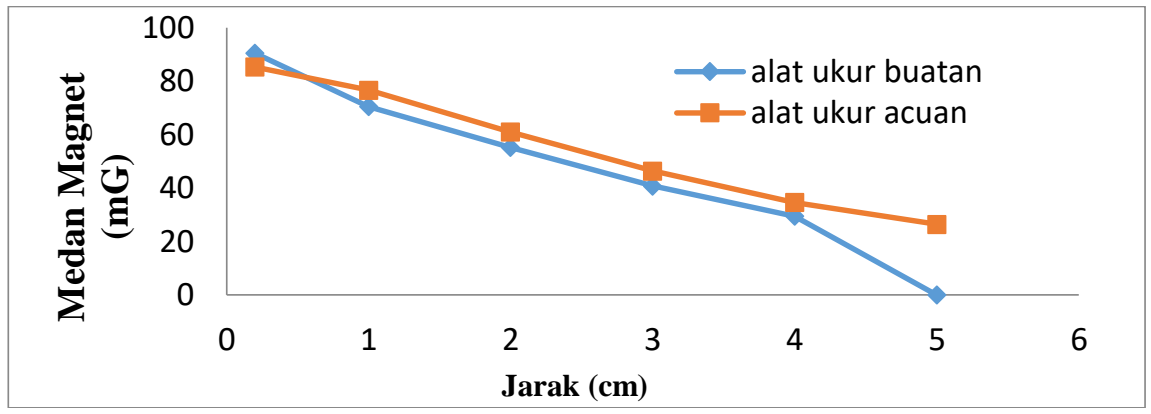

(c) 


\section{Hubungan Pengukuran Medan Magnet terhadap Jumlah Lilitan Kawat dan Arus Listrik pada Selenoida}

Grafik yang didapatkan dari hasil pengukuran medan magnet terhadap jumlah lilitan dan arus listrik menggunakan alat ukur buatan dan alat ukur acuan dapat dilihat seperti pada Gambar 6 .

Dari Gambar 6 didapatkan bahwa semakin banyak jumlah lilitan dan kuat arus listrik yang diberikan, maka semakin besar medan magnet yang dihasilkan oleh selenoida. Hal yang sama dengan yang dipaparkan oleh Salomo, dkk (2016), dimana jumlah lilitan dan arus listrik sangat berpengaruh terhadap besarnya kuat medan magnet yang dihasilkan. Hubungan antara medan magnet terhadap jumlah lilitan dan kuat arus listrik adalah linear.

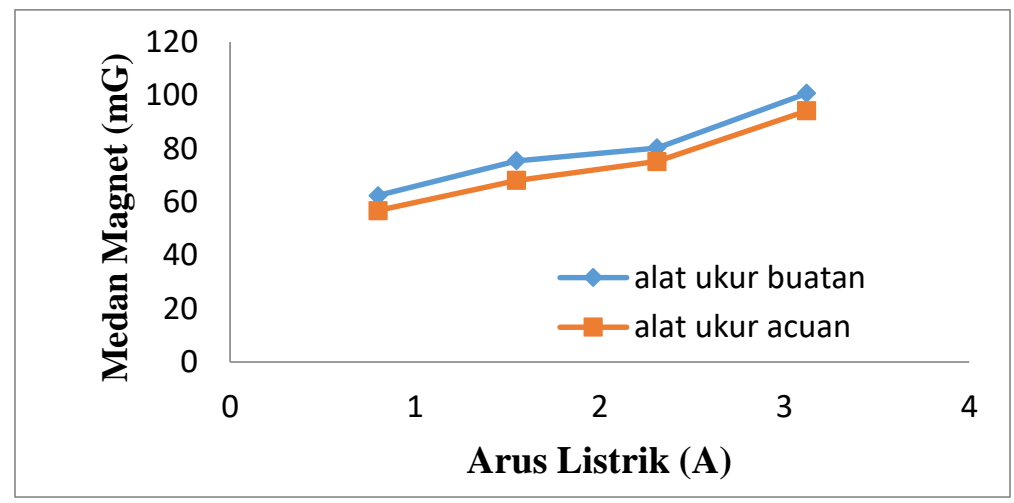

(a)

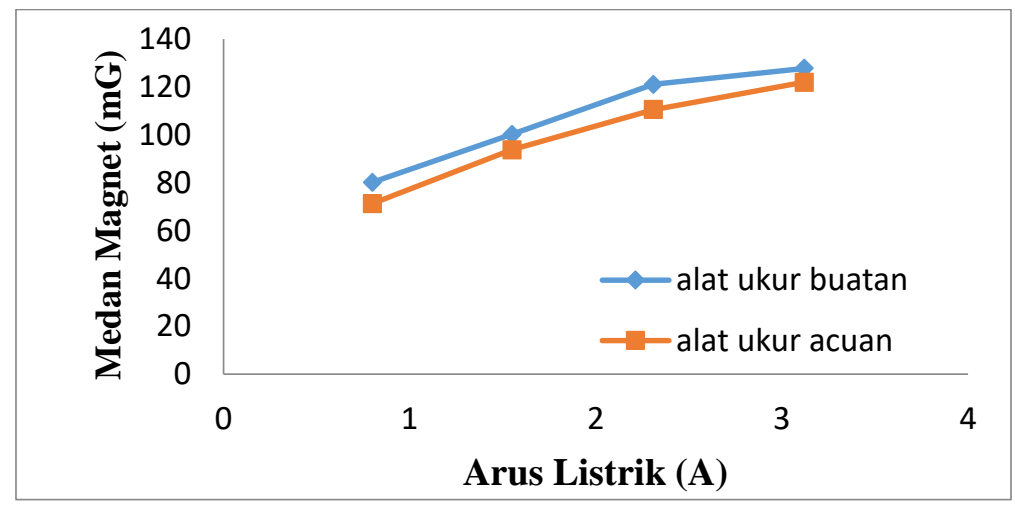

(b)

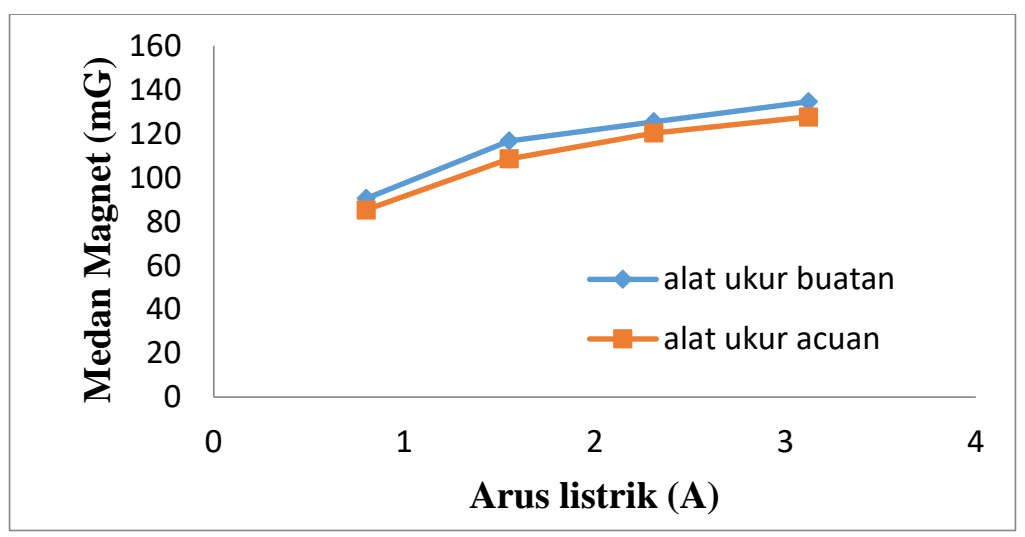

(c)

GAMBAR 6. Hubungan Medan Magnet Terhadap Jumlah Lilitan Kawat dan Kuat Arus Listrik (a) 1000 lilitan, (b)1200 lilitan, (c) 1400 lilitan 


\section{Perbandingan Pengukuran Medan Magnet Menggunakan Alat Ukur Medan Magnet dan Alat Ukur Acuan}

Hasil pengukuran yang telah didapat dari alat ukur buatan dan alat ukur acuan dibandingkan dengan melihat gradien dari grafik pengukuran medan magnet terhadap jarak, jumlah lilitan dan arus listrik.

Perbandingan hasil pengukuran medan magnet terhadap variasi jarak menggunakan alat ukur buatan dan alat ukur acuan, dapat dilihat seperti Gambar 7.

Hasil dari perhitungan menggunakan alat ukur buatan dengan gradien $\left(\mathrm{m}_{1}\right)$ sebesar -9.0185 dan pengukuran menggunakan alat ukur acuan dengan gradien $\left(\mathrm{m}_{2}\right)$ sebesar -7.8694. Dari gradien tersebut maka dapat dihitung \% errornya, yaitu:

$$
\begin{aligned}
\% \text { Error } & =\left[\frac{m_{1}-m_{n}}{m_{n}}\right] \times 100 \% \\
& =\left[\frac{-9.0185-7.8694}{-7.8694}\right] \times 100 \% \\
& =\frac{-1.1491}{-7.8694} \times 100 \% \\
& =0.146 \times 100 \% \\
& =14.60 \%
\end{aligned}
$$

Perbandingan pengukuran medan magnet terhadap jarak menggunakan alat ukur buatan dengan alat ukur acuan didapatkan hasil error, sebesar $14.60 \%$.

Perbandingan hasil pengukuran medan magnet terhadap jumlah lilitan menggunakan alat ukur buatan dan alat ukur acuan dapat dilihat pada Gambar 8.

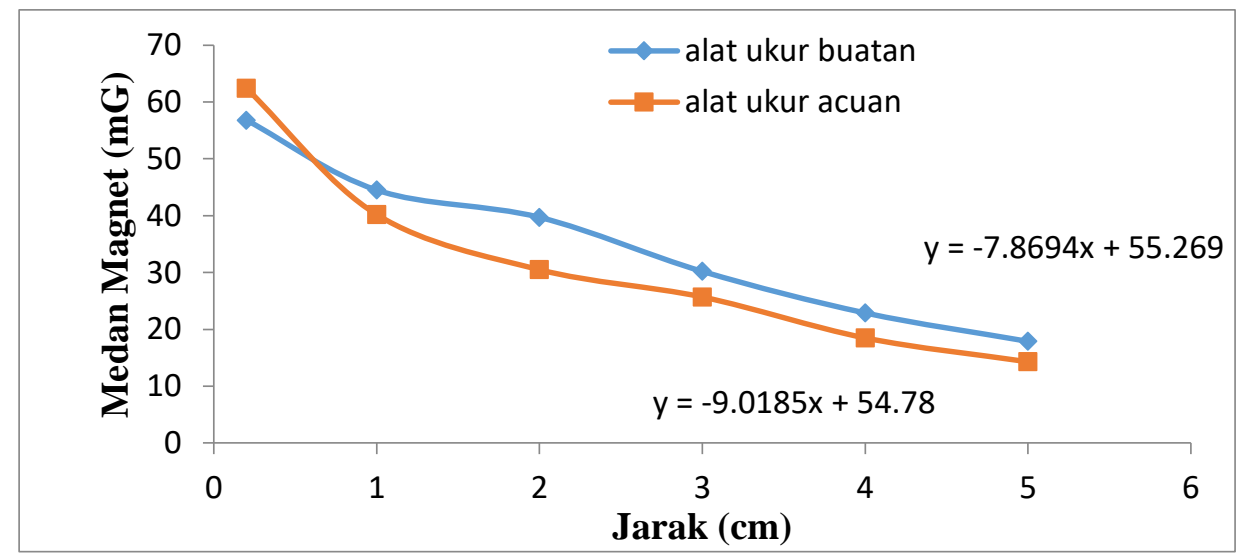

GAMBAR 7. Perbandingan Pengukuran Medan Magnet Terhadap Jarak Menggunakan Alat Ukur Buatan dan Alat Ukur Acuan

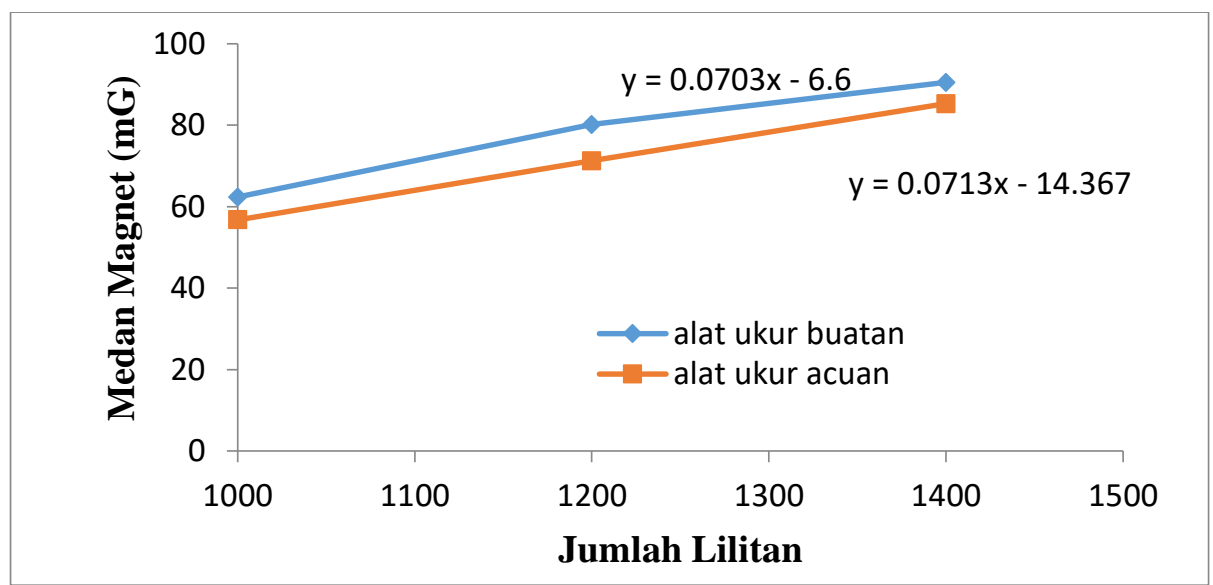

GAMBAR 8. Perbandingan Pengukuran Medan Magnet Terhadap Jumlah Lilitan Menggunakan Alat Ukur Buatan dan Alat Ukur Acuan 
Hasil dari perhitungan menggunakan alat ukur buatan dengan gradien $\left(\mathrm{m}_{1}\right)$ sebesar 0.0713 dan pengukuran menggunakan alat ukur acuan dengan gradien $\left(\mathrm{m}_{2}\right)$ sebesar 0.0703. Dari gradien tersebut maka dapat dihitung \% errornya, yaitu:

$$
\begin{aligned}
\% \text { Error } & =\left[\frac{m_{1}-m_{2}}{m_{2}}\right] \times 100 \% \\
& =\left[\frac{0.0713-0.0703}{0.0703}\right] \times 100 \% \\
& =\frac{0.001}{0.0703} \times 100 \% \\
& =0.014 \times 100 \% \\
& =1.42 \%
\end{aligned}
$$

Perbandingan pengukuran medan magnet terhadap jumlah lilitan menggunakan alat ukur buatan dengan menggunakan alat ukur acuan didapatkan hasil error, sebesar $1.42 \%$.

Perbandingan hasil pengukuran medan magnet terhadap arus listrik menggunakan alat ukur buatan dan alat ukur acuan, dapat dilihat seperti Gambar 9.

Hasil dari perhitungan menggunakan alat ukur buatan dengan gradien $\left(\mathrm{m}_{1}\right)$ sebesar 15.566 dan pengukuran menggunakan alat ukur acuan dengan gradien $\left(\mathrm{m}_{2}\right)$ sebesar 15.498. Dari gradien tersebut maka dapat dihitung \% errornya, yaitu:

$$
\begin{aligned}
\% \text { Error } & =\left[\frac{m_{1}-m_{2}}{m_{2}}\right] \times 100 \% \\
& =\left[\frac{15.566-15.498}{15.498}\right] \times 100 \% \\
& =\frac{0.068}{15.498} \times 100 \% \\
& =0.004 \times 100 \% \\
& =0.44 \%
\end{aligned}
$$

Perbandingan pengukuran medan magnet terhadap jumlah arus listrik menggunakan alat ukur buatan dengan menggunakan alat ukur acuan didapatkan hasil error, sebesar $0.44 \%$.

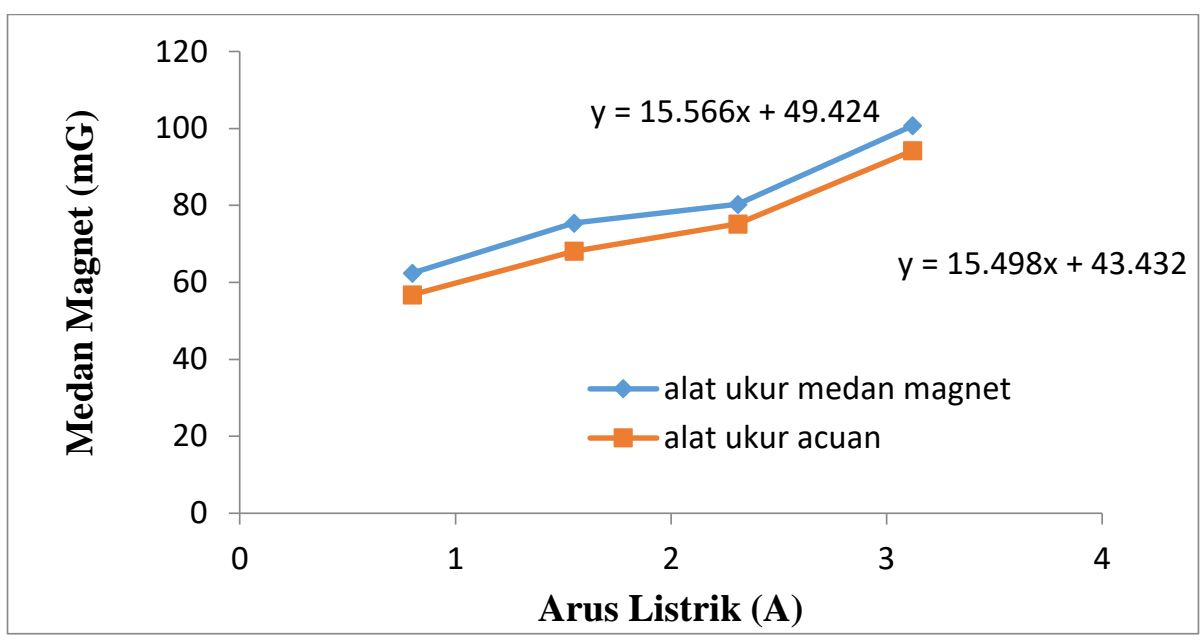

GAMBAR 9. Perbandingan Pengukuran Medan Magnet Terhadap Arus Listrik Menggunakan Alat Ukur Buatan dan Alat Ukur Acuan 


\section{KESIMPULAN}

Alat ukur medan magnet dirancang menggunakan sensor efek hall sebagai alat pendeteksi magnet. Pengaruh letak posisi pengukuran sensor mempengaruhi besar medan magnet yang terbaca oleh sensor. Jarak terdekat yang dapat terdeteksi oleh sensor efek hall adalah $0,2 \mathrm{~cm}$.

Hasil perbandingan pengukuran alat ukur medan magnet dengan menggunakan menggunakan alat ukur acuan didapatkan \% error untuk medan magnet terhadap jarak, jumlah lilitan dan arus listrik sebesar $14.60 \%$, $1.42 \%$, dan $0.44 \%$.

\section{DAFTAR PUSTAKA}

Ardiansyah, A., Ardianti, R., Nana, N. (2019). Medan magnet pada solenoida. https://doi.org/10.31227/osf.io/f4ykh

Erlangga, I. S. (2017). Pembuatan alat ukur medan magnet pada kumparan Helmholtz menggunakan sensor Ugn3503 yang dilengkapi dengan interface digital, Tesis. Universitas Brawijaya.

Junaidi, \& Prabowo, Y. D. (2018). Project sistem kendali elektronik berbasis arduino. AURA.

Novitasari, V., Agustrina, R., Irawan, B., \& Yulianty, Y. (2019). Pertumbuhan vegetatif tanaman tomat (Lycopersicum esculentum Mill.) dari benih lama yang diinduksi kuat medan magnet 0,1 mT, 0,2 $\mathrm{mT}$, dan 0,3 mT. Jurnal Biologi Indonesia 15(2),

219-225. https://doi.org/10.14203/jbi.v15i2.3816

Pambuka, R. N., \& Rahardjo, D. T. (2018). Pembuatan alat eksperimen induksi magnet pada toroida menggunakan arduino dan hall effect sensor. Jurnal Materi dan Pembelajaran Fisika 2(8), 3338.

https://doi.org/10.20961/jmpf.v8i2.28436

Prasetyo, A. R., Kaloeti, D. V., Rahmandani, A., Salma, \& Arianti, J. (2020). Buku ajar metodologi eksperimen. Universitas Diponegoro.
Premono, P., Soedjarwanto, N., \& Alam, S. (2015). Rancang bangun alat instrumentasi pengukuran digital kuat medan magnetik dengan menggunakan mikrokontroler Atmega8535. Jurnal Rekayasa dan Teknologi Elektro, 9(3), 160-170. https://doi.org/10.23960/elc.v9n3.181

Salomo, S., Erwin, E., \& Ardiyani, G. (2016). Perubahan kuat medan magnet sebagai fungsi jumlah lilitan pada kumparan Helmholtz. Jurnal Komunikasi Fisika Indonesia, 13(12), 814-819. http://dx.doi.og/10.31258/jkfi.13.12.814819

Suwarti. (2018). Analisis pengaruh intensitas matahari, suhu permukaan \& sudut pengarah terhadap kinerja panel surya. Jurnal Teknik Energi, 14(3), 78-85. http://dx.doi.org/10.32497/eksergi.v14i3. 1373

\section{Penulis:}

Leni Yanti Waruwu

Program Studi Pendidikan Fisika, STKIP PGRI Sumatera Barat. Jalan Gunung Pangilun, Gajah Mada.

Email: 13leniwaruwu@gmail.com

Aidhia Rahmi

Program Studi Pendidikan Fisika, STKIP PGRI Sumatera Barat. Jalan Gunung Pangilun, Gajah Mada.

Email: aidhia@stkip-pgri-sumbar.ac.id

Megasyani Anaperta

Program Studi Pendidikan Fisika, STKIP PGRI Sumatera Barat. Jalan Gunung Pangilun, Gajah Mada.

Email: megasyani@stkip-pgri-sumbar.ac.id 